Przegląd Badań Edukacyjnych

ISSN 1895-4308

nr $18(1 / 2014)$, s. 37-56

ORYGINALNE

ARTYKUtY

BADAWCZE

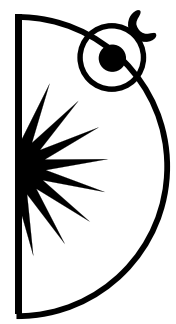

Marzena Walaszek*

\title{
Pochodzenie terytorialne uczniów szkół ponadgimnazjalnych jako kryterium delimitacji miejskich obszarów funkcjonalnych Włocławka, Grudziądza i Inowrocławia
}

DOI: http://dx.doi.org/10.12775/PBE.2014.004

\section{Wprowadzenie}

Według Maika (1992) funkcje miasta rozpatruje się w odniesieniu do zlokalizowanych w nim działalności gospodarczych i społecznych, które można podzielić na produkcyjne i usługowe. Funkcje usługowe zlokalizowane w mieście pozwalają na zaspokojenie potrzeb życiowych mieszańców m.in. w zakresie życia kulturalnego, oświaty czy ochrony zdrowia. W zależności od stopnia rozwoju danej działalności w mieście, kształtuje się jego ranga w systemie osadniczym regionu. Analiza funkcji miejskich oparta jest na teorii miejsc centralnych, którą po raz pierwszy sformułował W. Christaller w 1933 roku.

W świetle teorii Christallera miasta są miejscowościami centralnymi nie ze względu na położenie centralne, ale dlatego, że pełnią funkcje centralne. Funkcje tego rodzaju obejmują działalności o znaczeniu ponadlokalnym, a zaliczyć do nich można m.in.: handel, usługi kulturalne, oświatowe, zdrowotne, finan-

* Doktorantka jest stypendystką Fundacji Uniwersytetu im. Adama Mickiewicza w Poznaniu na rok akademicki 2013/2014. 
sowe, a także niektóre działy przemysłu. Zgodnie z teorią miejsc centralnych, miasto jest centrum funkcjonalnym zaplecza i czynnikiem, który kształtuje to zaplecze w istotny sposób. Miasto wykonuje w stosunku do swego otoczenia funkcje centralne, wpływając na wytwarzanie się na zapleczu więzi gospodarczych, społecznych i kulturowych (Maik, 1992).

Badania terytorialnego pochodzenia uczniów w szkołach ponadgimnazjalnych mogą posłużyć ocenie relacji funkcjonalnych pomiędzy miastem centralnym a jego zapleczem. Na podstawie przeprowadzonych przez autorkę badań pochodzenia terytorialnego uczniów szkół ponadgimnazjalnych stwierdzić należy, że im wyższy poziom nauczania i większa specjalizacja szkoły, tym relacje miasta z jego otoczeniem są silniejsze ${ }^{1} 1$ (jest to związane również z lokalizacją i dostępnością szkół, która jest lepsza w przypadku szkół podstawowych i gimnazjalnych niż np. placówek ponadgimnazjalnych).

Stopień wykształcenia funkcji ośrodków miejskich wpływa na rozwój społeczno-gospodarczy całych regionów. Aktualnie prowadzona polityka rozwoju w Polsce, wynikająca $\mathrm{z}$ dokumentów strategicznych 22 rangi krajowej, wyraźnie odchodzi od planowania sektorowego na rzecz planowania zintegrowanego. Nową kategorią obszarów rozwojowych są miejskie obszary funkcjonalne ${ }^{3} 3$, wyznaczone w Koncepcji Przestrzennego Zagospodarowania Kraju 2030 (KPZK 2030). W dokumencie tym dokonano delimitacji obszarów metropolitalnych, regionalnych i subregionalnych, które ze względu na wysokie wartości wskaźników społeczno-gospodarczych, a przede wszystkim ze względu na pełnione funkcje, mają największe znaczenie dla zrównoważonego, policentrycznego rozwoju kraju.

Naobszarze województwakujawsko-pomorskiego wyznaczono dwagłówne ośrodki metropolitalne - Toruń i Bydgoszcz. Uznano, że miasta te posiadają duży potencjał gospodarczy rozumiany jako ponadkrajowa atrakcyjność inwestycyjna, szeroką ofertę usług wyższego rzędu czy zdolność do utrzymywania relacji handlowych, naukowych, edukacyjnych, kulturowych z międzynarodowymi

${ }^{1}$ Potwierdzają to wyniki prezentowanych w artykule badań, jak i wyniki badań terytorialnego pochodzenia uczniów szkół ponadgimnazjalnych miasta Poznania, przeprowadzonych w listopadzie 2013 roku.

2 Do najważniejszych dokumentów strategicznych obowiązujących w Polsce należą m.in.: Strategia Rozwoju Kraju 2007-2015, Krajowa Strategia Rozwoju Regionalnego 2010-2020: Regiony, Miasta, Obszary wiejskie, Koncepcja Przestrzennego Zagospodarowania Kraju 2030

${ }^{3}$ Według definicji KPZK 2030 ,miejski obszar funkcjonalny jest układem osadniczym ciągłym przestrzennie, złożonym z odrębnych administracyjnie jednostek. Obejmuje zwarty obszar miejski oraz powiązaną z nim funkcjonalnie strefę zurbanizowaną 
metropoliami. W sieci osadniczej województwa kujawsko-pomorskiego wyróżniono również dwa obszary funkcjonalne ośrodków regionalnych - Grudziądz i Włocławek - oraz jeden ośrodek subregionalny - Inowrocław. Jak wskazują zapisy KPZK 2030, obszary funkcjonalne ośrodków regionalnych i subregionalnych mogą zapewniać spójny i policentryczny rozwój oraz zwiększać przestrzenną i funkcjonalną równowagę systemu osadniczego. Obowiązkiem przeprowadzenia delimitacji miejskich obszarów funkcjonalnych, wraz z określeniem ich funkcjonalnej strefy zurbanizowanej objęto wszystkie ośrodki wojewódzkie, w tym metropolitalne. W przypadku miejskich obszarów funkcjonalnych regionalnych, subregionalnych i lokalnych nie wprowadzono takiej konieczności, sygnalizując możliwość decydowania o wykonaniu takiej delimitacji na poziomie regionalnym.

Zgodnie z zapisami Strategii Rozwoju Województwa Kujawsko-Pomorskiego do 2020, silną stroną regionu jest unikatowy w skali kraju kształt sieci osadniczej, stwarzającej bardzo sprzyjające warunki obsługi ludności na każdym poziomie hierarchicznym i funkcjonalnym. Jednym z celów strategicznych województwa kujawsko-pomorskiego do roku 2020 jest nadanie impulsów rozwojowych wschodniej części województwa, zwłaszcza Grudziądzowi i Włocławkowi, które pełnią szczególną funkcję w stymulowaniu rozwoju społecznego i gospodarczego otaczających powiatów.

Jednym z kryteriów delimitacji obszarów miejskich może być badanie przepływów uczniów z miejsca zamieszkania do placówki szkolnej. Należy podkreślić, że z uwagi na brak dostępnych danych i czasochłonność zbierania ankiet w szkołach, badanie tego typu są rzadko wykorzystywane w procedurach delimitacyjnych miast. O możliwości zastosowania badań dojazdów uczniów do szkół w procedurach delimitacyjnych przemawia fakt, że przepływy uczniów są efektem realnych powiązań przestrzenno-funkcjonalnych pomiędzy ośrodkiem edukacji a otoczeniem pozostającym w strefie jego oddziaływania. Badania pochodzenia terytorialnego uczniów obrazują zasięg oddziaływania pojedynczych placówek szkolnych, jak też całego szkolnictwa jako ważnego elementu rangi ośrodków usługowych.

Temat pochodzenia terytorialnego uczniów jest niestety ciągle słabo osadzony w literaturze naukowej. W Polsce badania dotyczące zasięgów oddziaływań szkół są w ostatnich latach głównie przedmiotem ekspertyz sporządzanych na zlecenie organów samorządowych lub rządowych. Należałoby tutaj wymienić m.in. prace badawcze Guzika (2003), Bajerskiego (2010), Plazy (2012), Walaszek (2012) i Bula (2013) czy ekspertyzę Śleszyńskiego, Czapiewskiego i Kozaka (2011). 


\section{Cel, źródła i metody badań}

Celem artykułu jest zaprezentowanie wyników badań terytorialnego pochodzenia uczniów szkół ponadgimnazjalnych Grudziądza, Włocławka i Inowrocławia oraz wskazanie zastosowania tego typu badań w procesach delimitacji miejskich obszarów funkcjonalnych.

W artykule zaprezentowano wyniki badań zrealizowanych dla Urzędu Marszałkowskiego Województwa Kujawsko-Pomorskiego w Toruniu, które opracowane zostały w formie ekspertyzy naukowej o nazwie: „Określenie specyfiki oraz przygotowanie propozycji delimitacji miejskich obszarów funkcjonalnych Włocławka, Grudziądza i Inowrocławia)". Dokument opracowany został przez zespół ekspertów Centrum Badań Metropolitalnych Uniwersytetu im. Adama Mickiewicza w Poznaniu pod kierunkiem prof. dr hab. Tomasza Kaczmarka we wrześniu 2013 roku.

Źródłem danych na temat lokalizacji oraz ogólnej charakterystyki szkół ponadgimnazjalnych w Inowrocławiu, Grudziądzu i Włocławku była baza Centrum Informatycznego Edukacji (www.cie.men.gov.pl), w której publikowane są dane pochodzące z Systemu Informacji Oświatowej. Pełna baza szkół pozyskana z SIO zawiera m.in. dane dotyczące: położenia szkoły (województwo, powiat, gmina, miejscowość), nazwę i adres szkoły, publiczność placówki, kategorię uczniów, specjalizację szkoły, identyfikację organu prowadzącego i rejestrującego, liczbę uczniów, w tym dziewcząt, liczbę oddziałów szkolnych, liczbę zatrudnionych nauczycieli. Warto zauważyć, że dane publikowane na stronach CIE, pochodzą z tzw. starego Systemu Informacji Oświatowej 4 .

Badanie 80 placówek szkolnych w miejscowościach Grudziądz, Inowrocław i Włocławek przeprowadzono w dniach od 20 sierpnia 2013 r. do 16 września 2013 r. Do dyrekcji szkół ponadgimnazjalnych (publicznych i niepublicznych) skierowano drogą pisemną ankiety dotyczące liczby i miejsca zamieszkania uczniów wg gmin. Ankiety rozesłane zostały do wszystkich szkół publicznych i niepublicznych, z pominięciem szkół przy zakładach karnych i Młodzieżowych Ośrodkach Szkolno-Wychowawczych. Objęcie badaniem sektora szkół niepublicznych zakładało uzyskanie pełnego obrazu oddziaływania szkolnictwa ponadgimnazjalnego (warto podkreślić, że w przypadku szkół policealnych udział placówek niepublicznych osiaga w tych miastach ok. 50\%

${ }^{4}$ Od roku szkolnego 2013/2014 w szkołach rozpoczęło się testowanie tzw. nowego SIO, które zawierać ma szeroką bazę danych na temat szkół, w tym tzw. szczegółowe informacje dziedzinowe na temat uczniów. 
i jest najwyższy wg typów szkół ponadgimnazjalnych). Niestety, zwrot ankiet ze szkół niepublicznych był niewielki (1 szkoła). Większość danych z ww. placówek pozyskano na stan 1 września 2013 r. (12 z 15 szkół).

Otrzymano poprawnie wypełnione ankiety z 25 szkół (8 szkół z Grudziądza, 8 szkół z Inowrocławia i 9 szkół z Włocławka). W przesłanych przez szkoły ankietach wskazano miejsca zamieszkania 3322 uczniów:

- 1206 uczniów zamiejscowych kształcących się w szkołach ponadgimnazjalnych Grudziądza,

- 1237 uczniów kształcących się w szkołach ponadgimnazjalnych Włocławka,

- 879 uczniów zamiejscowych kształcących się w szkołach ponadgimnazjalnych Inowrocławia.

Decydującą kwestią dla wyznaczenia stref oddziaływania szkolnictwa ponadgimnazjalnego jest dobór odpowiednich kryteriów delimitacji. Już podczas wstępnej analizy zebranego materiału badawczego zauważono, że dla każdego $\mathrm{z}$ badanych miast występuje większa bądź mniejsza liczba gmin, które dominują pod względem liczby uczniów zamiejscowych w każdej z badanych szkół. Pozwoliło to na opracowanie jednolitych dla wszystkich 3 miast kryteriów delimitacji stref oddziaływania szkolnictwa ponadgimanzajlnego. Szczegółowa analiza danych wykazała, że celowe będzie wyznaczenie dwóch typów obszarów: o silnym i słabszym oddziaływaniu szkolnictwa ponadgimnazjalnego (Tabela 1).

Tabela 1. Kryteria delimitacji strefy o silnych i słabszych powiązaniach szkolnictwa ponadgimnazjalnego

\begin{tabular}{|c|c|c|}
\hline Kryterium & $\begin{array}{c}\text { Strefa o silnym oddziaływaniu } \\
\text { szkolnictwa }\end{array}$ & $\begin{array}{c}\text { Strefa o słabszym oddziaływaniu } \\
\text { szkolnictwa }\end{array}$ \\
\hline $\begin{array}{c}\text { Liczba uczniów dojeżdżających } \\
\text { do miasta: }\end{array}$ & $\geq 50$ osób & od 10-49 osób \\
\hline $\begin{array}{c}\text { Odsetek uczniów dojeżdżających } \\
\text { z danej gminy w kategorii } \\
\text { wiekowej 15-19 lat: }\end{array}$ & $\geq 10 \%$ & $5-9,9 \%$ \\
\hline
\end{tabular}

Źródło: opracowanie własne

Powyżej przyjęte kryteria są logiczne i poparte szczegółową analizą materiału badawczego, z którego wynika, że pewne gminy wyraźnie „odstają” pod względem wartości liczbowych od pozostałych. Gminy o liczbie uczniów poniżej 10 i odsetku uczniów w kategorii wiekowej 15-19 lat poniżej 5\%, choć stanowią większość, są jednostkami o bardzo słabych powiązaniach szkolnych 
$\mathrm{z}$ badanymi miastami i z uwagi na ich znaczną liczbę w zestawieniach tabelarycznych zostały pominięte.

\section{Charakterystyka szkolnictwa ponadgimnazjalnego w Grudziądzu, Włocławku i Inowrocławiu}

W Grudziądzu, Inowrocławiu i Włocławku w roku szkolnym 2012/2013 naukę w szkołach ponadgimnazjalnych (publicznych i niepublicznych łącznie, dla dorosłych i młodzieży, bez specjalnych) pobierało 29513 osób. Pod względem liczby uczniów kształcących się w szkołach ponadgimnazjalnych pierwszą pozycję zajął Włocławek, w którym w szkołach tych uczyło się 12938 osób. W Grudziądzu liczba uczniów szkół ponadgimnazjalnych w roku szkolnym 2012/2013 wynosiła 9122, a w Inowrocławiu 7453. Najbardziej ,popularnymi” wśród szkół ponadgimnazjalnych są licea ogólnokształcące, w których łącznie w badanych 3 miastach naukę pobierało 10 470, a więc ponad 1/3 ogółu uczniów. Znaczna część uczniów kształciła się też w technikach (7311) oraz szkołach policealnych (6768). Nieznaczna część osób wybrała kształcenie w zasadniczych szkołach zawodowych - w badanych 3 miastach to 2874 uczniów.

\section{Grudziądz}

W Grudziądzu w roku szkolnym 2012/2013 zlokalizowanych było 8 zasadniczych szkół zawodowych, 13 liceów ogólnokształcących, 6 techników i 4 szkoły policealne. Publiczne szkoły zawodowe w Grudziądzu prowadzone są głównie przez Miasto Grudziądz (6 szkół), Stowarzyszenie na rzecz Pomocy Młodzieży „Junak” (1 szkoła) oraz Ministra ds. sprawiedliwości (szkoła zawodowa przy Zakładzie Karnym nr 1 w Grudziądzu). Wśród uczniów kształcących się w Grudziądzu w roku szkolnym 2012/2013 dominowali uczniowie liceów ogólnokształcących (36\%) oraz techników i zasadniczych szkół zawodowych (po 23\%).

W publicznych zasadniczych szkołach zawodowych w Grudziądzu w roku szkolnym 2012/2013 naukę pobierało łącznie 1041 uczniów (w tym 28 w zakładzie karnym). W Grudziądzu w roku szkolnym 2012/2013 funkcjonowało 13 liceów ogólnokształcących (łącznie z liceami dla dorosłych). W roku szkolnym 2012/2013 do liceów ogólnokształcących publicznych w Grudziądzu uczęszczało łącznie 2144 uczniów, pobierających naukę w 71 oddziałach szkolnych. W Grudziądzu funkcjonowały również 3 licea uzupełniające niepubliczne oraz jedno publiczne liceum uzupełniające, z liczbą 159 uczniów, którzy naukę pobierali w 7 oddziałach szkolnych. W roku szkolnym 2012/2013 działało w Gru- 
dziądzu 6 techników publicznych, do których uczęszczało 2096 uczniów (118 oddziałów) oraz dwa publiczne technika uzupełniające, do których uczęszczało 83 uczniów, kształcących się w 5 oddziałach szkolnych. W Grudziądzu funkcjonuje Państwowa Szkoła Muzyczna I i II stopnia, prowadzona przez Ministra ds. Kultury i Dziedzictwa Narodowego, w której w roku szkolnym 2012/2013 kształciło się 42 uczniów. Młodzież posiada też możliwość kształcenia się w 4-letnim liceum plastycznym publicznym. $\mathrm{Z}$ tej formy nauki, w roku szkolnym 2012/2013 skorzystało 73 uczniów.

Tabela 2. Typy i liczba szkół ponadgimnazjalnych w Grudziądzu w roku szkolnym 2012/2013

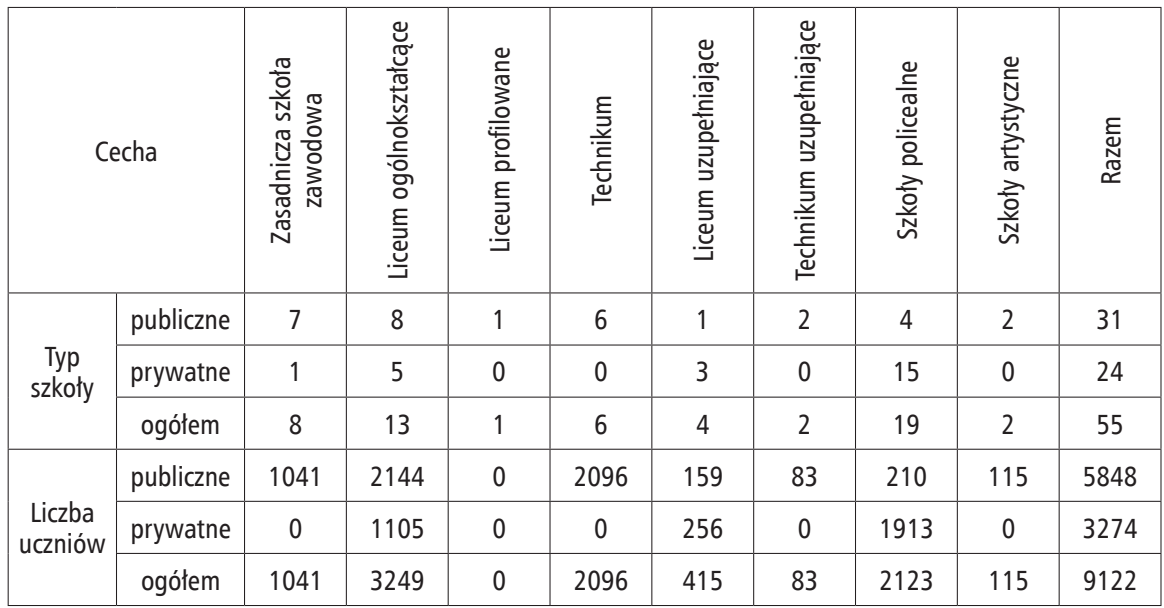

Źródło: opracowanie własne na podstawie BDL GUS i SIO

\section{Wloclawek}

W roku szkolnym 2012/2013 we Włocławku funkcjonowało łącznie 11 zasadniczych szkół zawodowych (wszystkie o charakterze publicznym, w tym dwie prowadzone przez Włocławskie Stowarzyszenie Oświatowe „Cogito"), w których w 66 oddziałach kształciło się 1201 uczniów. W roku szkolnym 2012/2013 we Włocławku działało 9 liceów ogólnokształcących publicznych, w których naukę pobierało 2847 uczniów (w 103 oddziałach szkolnych) oraz 12 liceów niepublicznych. We Włocławku działały również 4 licea profilowane publiczne, w których w 12 oddziałach naukę pobierało 276 uczniów, oraz 2 licea uzupełniające publiczne (50 uczniów w roku szkolnym 2012/2013) oraz 7 liceów niepublicznych. We Włocławku w roku szkolnym 2012/2013 funkcjo- 
nowało 7 techników publicznych, do których uczęszczało 2942 uczniów oraz 1 technikum niepubliczne. Swoją działalność prowadziło również 5 techników uzupełniających publicznych (259 uczniów).

We Włocławku w roku szkolnym 2012/2013 funkcjonowało 5 publicznych szkół policealnych i 12 niepublicznych szkół policealnych. W publicznych szkołach policealnych naukę pobierało 260 uczniów. We Włocławku działają dwie szkoły artystyczne: szkoła muzyczna publiczna II stopnia (69 uczniów) a także prywatna szkoła sztuk pięknych.

Tabela 3. Typy i liczba szkół ponadgimnazjalnych we Włocławku w roku szkolnym 2012/2013

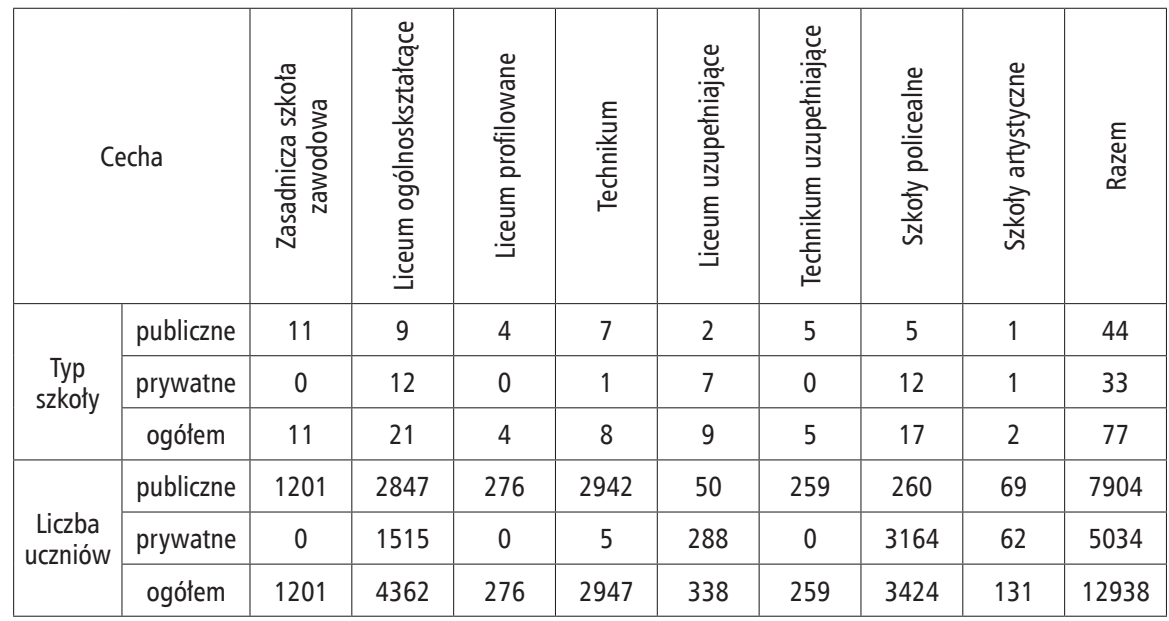

Źródło: opracowanie własne na podstawie BDL GUS i SIO

We Włocławku funkcjonuje najwięcej szkół ponadgimnazjalnych wśród 3 badanych miast, ale jest też najszersza oferta kształcenia. Również wśród 3 badanych miast we Włocławku najbardziej rozwinięty jest sektor szkolnictwa niepublicznego, np. wśród aż 21 liceów ogólnokształcących ponad połowa $\mathrm{z}$ nich to szkoły niepubliczne. Podobnie, w przypadku szkół ponadgimnazjalnych aż 12 z 17 szkół to placówki niepubliczne. Szkoły niepubliczne niewątpliwie poszerzają ofertę edukacyjną miasta, ułatwiając dostęp do zawodów wyspecjalizowanych. We Włocławku udział uczniów kształcących się w szkołach policealnych jest najwyższy spośród badanych miast (26\%). Biorąc pod uwagę mocno ukierunkowany typ kształcenia w szkołach policealnych (szkoły służb ochrony, szkoły medyczne itd.), edukacyjna oferta Włocławka wydaje się najbardziej zróżnicowana. 


\section{Inowroclaw}

W roku szkolnym 2012/2013 w Inowrocławiu funkcjonowało łącznie 7 zasadniczych szkół zawodowych, w tym jedna niepubliczna, prowadzona przez Cech Rzemiosł Różnych. W publicznych szkołach zawodowych naukę pobierało 632 uczniów w 28 oddziałach szkolnych. W roku szkolnym 2012/2013 w Inowrocławiu działało 9 liceów ogólnokształcących, w tym 5 publicznych, w których kształciło się 2293 uczniów, w 67 oddziałach szkolnych. W Inowrocławiu istniały 4 licea uzupełniające, w tym jedno publiczne, w którym w 2 oddziałach szkolnych naukę pobierało 52 uczniów.

W Inowrocławiu w roku szkolnym 2012/2013 funkcjonowało 8 techników, w tym 5 publicznych, w których naukę pobierało 2036 uczniów, w 75 oddziałach szkolnych. Działały również 2 technika uzupełniające, w których uczęszczało 72 uczniów (4 oddziały szkolne). W Inowrocławiu znajdowało się 10 szkół policealnych, w tym 2 publiczne. W roku szkolnym 2012/2013 tylko w publicznych szkołach policealnych naukę pobierało 427 uczniów w 16 oddziałach szkolnych. W mieście działały również dwie szkoły muzyczne II stopnia (6 i 4-letnia), kształcąc w roku szkolnym 2012/2013 103 uczniów.

Tabela 4. Typy i liczba szkół ponadgimnazjalnych w Inowrocławiu w roku szkolnym 2012/2013

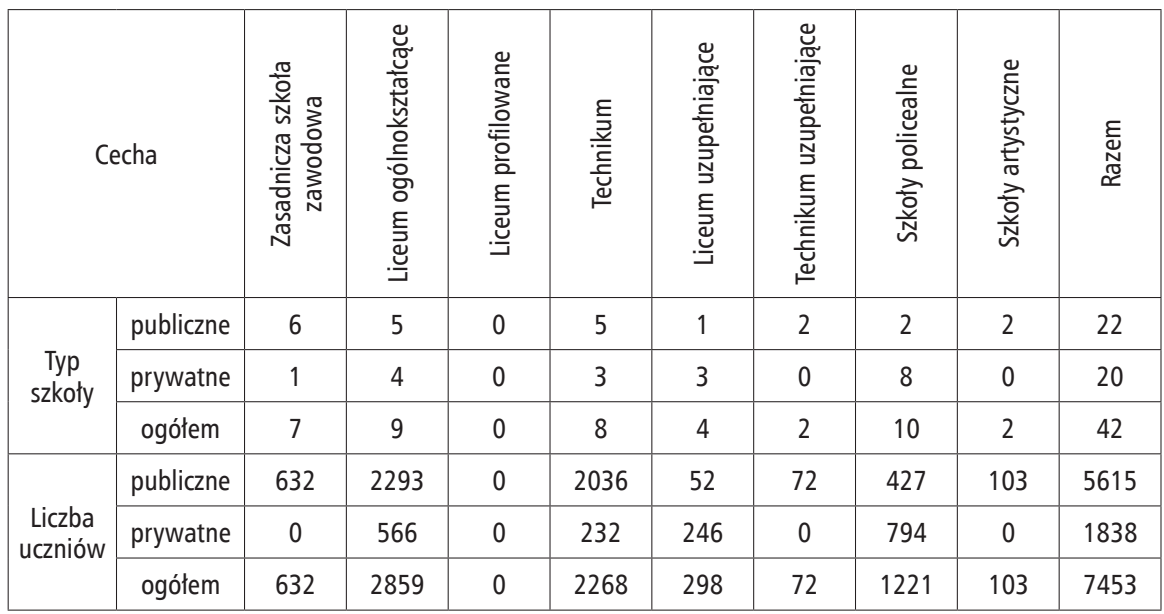

Źródło: opracowanie własne na podstawie BDL GUS i SIO 


\section{Pochodzenie terytorialne uczniów szkół ponadgimnazjalnych}

\section{Grudziądz}

Badania zasięgu szkół ponadgimnazjalnych w Grudziądzu wykonane zostały w oparciu o dane dotyczące miejsc zamieszkania uczniów, nadesłane z 8 szkół (3 technika, 3 licea ogólnokształcące, 1 zasadniczą szkołę zawodową i 1 szkołę policealną). W ten sposób otrzymano informacje dotyczące miejsc zamieszkania 1206 uczniów zamiejscowych (spoza Grudziądza), spośród ogólnej liczby 2515 uczniów uczęszczających do ww. szkół (oznacza to, że 47,9\% stanowili uczniowie pozamiejscowi). W odniesieniu do ogólnej liczby uczniów kształcących się w Grudziądzu w szkołach ponadgimnazjalnych (9122) badaniem objęto 39,2\% wszystkich uczniów szkół ponadgimnazjalnych, 52,2\% uczniów techników, 22,3\% zasadniczych szkół zawodowych, 33,8\% liceów ogólnokształcących i 4,2\% szkół policealnych.

Najliczniejszą grupę uczniów dojeżdżających do szkół ponadgimnazjalnych w Grudziądzu stanowią uczniowie z gminy wiejskiej Grudziądz (213 uczniów), gminy Dragacz (116 uczniów) oraz gminy Łasin (104 uczniów). Znaczna liczba uczniów dojeżdża również z gmin: Gruta (98), Rogóźno (86), Radzyń Chełmiński (82), Warlubie (79), Świecie nad Osą (67), Nowe (66).

Największym udziałem młodzieży dojeżdżającej do szkół tego typu do Grudziądza charakteryzuje się gmina Rogóźno (29,25\%), gmina wiejska Grudziądz (27,20\%), Dragacz (26,42\%), Radzyń Chełmiński (21,75\%), Świecie n./Osą $(21,34 \%)$ oraz Gruta (20,94\%). W przedziale od 10-20\% mieszczą się gminy: Warlubie (17,83\%) oraz Łasin (18,6\%). Pozostałe gminy (od 5-9\%) charakteryzują się słabszymi powiązaniami z Grudziądzem (Nowe, Stolno, Płużnica, Jabłonowo Pomorskie, Jeżewo). Najsilniejsza strefa przestrzennych oddziaływań szkolnictwa ponadgimnazjalnego Grudziądza, biorąc pod uwagę odsetek uczniów w wieku 15-19 lat, w zasadzie domyka się w granicach powiatu grudziądzkiego.

Na podstawie przyjętych kryteriów wyodrębniono 8 gmin o silnym oddziaływaniu szkolnictwa ponadgimnazjalnego Grudziądza (Grudziądz-gmina wiejska, Dragacz, Łasin, Gruta, Rogóźno, Radzyń Chełmiński, Warlubie, Świecie n./Osą) oraz 5 gmin wchodzących w skład strefy o słabszym oddziaływaniu (Nowe, Jabłonowo Pomorskie, Stolno, Płużnica, Jeżewo). 

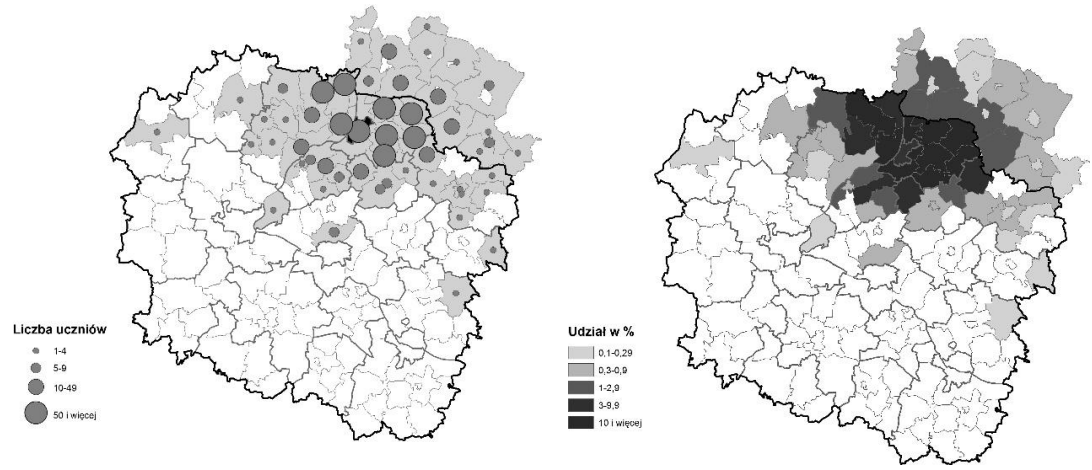

Ryc. 1. Liczba uczniów zamiejscowych i ich udział w ogólnej liczbie młodzieży w wieku 15-19 lat

źródło: opracowanie własne

Tabela 5. Wykaz gmin w strefie silnych i słabych oddziaływań szkolnictwa ponadgimnazjalnego z Grudziądzem

\begin{tabular}{|c|c|c|c|c|c|}
\hline Lp. & Gmina & Powiat & $\begin{array}{l}\text { Liczba uczniów } \\
\text { zamiejscowych }\end{array}$ & $\begin{array}{c}\text { Liczba osób } \\
\text { w wieku } \\
\text { 15-19 lat }\end{array}$ & $\begin{array}{c}\text { Odsetek uczniów } \\
\text { w wieku } \\
15-19 \text { lat }\end{array}$ \\
\hline \multicolumn{6}{|c|}{ Strefa silnych oddziaływań } \\
\hline 1 & $\begin{array}{l}\text { Grudziądz - } \\
\text { gmina }\end{array}$ & grudziądzki & 213 & 783 & 27,2 \\
\hline 2 & Dragacz & świecki & 116 & 439 & 26,42 \\
\hline 3 & Łasin & grudziądzki & 104 & 559 & 18,6 \\
\hline 4 & Gruta & grudziądzki & 98 & 468 & 20,94 \\
\hline 5 & Rogóźno & grudziądzki & 86 & 294 & 29,25 \\
\hline 6 & $\begin{array}{c}\text { Radzyń } \\
\text { Chełmiński }\end{array}$ & grudziądzki & 82 & 377 & 21,75 \\
\hline 7 & Warlubie & świecki & 79 & 443 & 17,83 \\
\hline 8 & Świecie nad Osą & grudziądzki & 67 & 314 & 21,34 \\
\hline \multicolumn{6}{|c|}{ Strefa słabszych oddziaływań } \\
\hline 1 & Nowe & świecki & 66 & 669 & 9,87 \\
\hline 2 & $\begin{array}{l}\text { Jabłonowo } \\
\text { Pomorskie }\end{array}$ & brodnicki & 36 & 662 & 5,44 \\
\hline 3 & Stolno & chełmiński & 33 & 387 & 8,53 \\
\hline 4 & Płużnica & wąbrzeski & 28 & 344 & 8,14 \\
\hline 5 & Jeżewo & świecki & 27 & 518 & 5,21 \\
\hline
\end{tabular}

źródło: opracowanie własne na podstawie badań ankietowych 


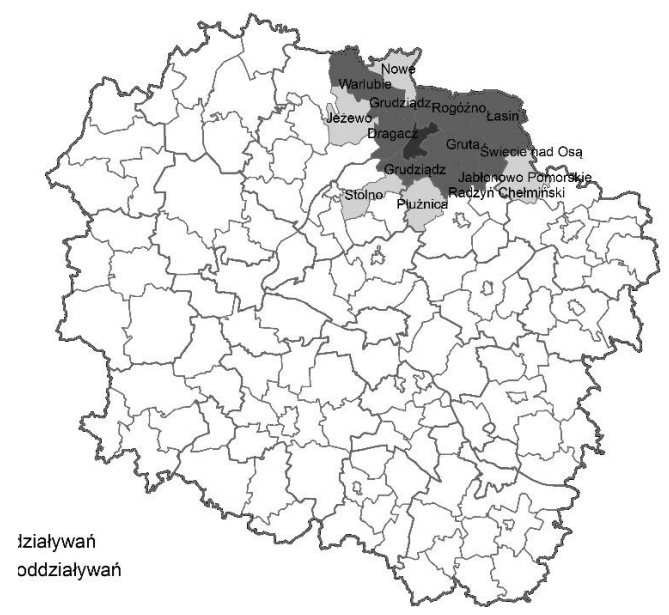

Ryc. 2. Strefy oddziaływań szkolnictwa ponadgimnazjalnego Grudziądza

źródło: opracowanie własne

\section{Włoclawek}

Dane dotyczące liczby i miejsca zamieszkania uczniów zamiejscowych kształcących się w szkołach ponadgimnazjalnych we Włocławku dotyczyły 9 szkół (4 licea ogólnokształcące, 1 liceum profilowane, 2 technika i 2 zasadnicze szkoły zawodowe). W ww. szkołach naukę w roku szkolnym 2012/2013 pobierało łącznie 2744 uczniów, w tym 1237 spoza Włocławka, co stanowi 45\%. Badaniem objęto 42,5\% uczniów liceów ogólnokształcących, 25\% uczniów liceów profilowanych, 27,8\% uczniów techników, 17,8\% uczniów zasadniczych szkół zawodowych. Ogółem badaniem objęto $21 \%$ z wszystkich uczniów kształcących się w szkołach ponadgimnazjalnych we Włocławku.

Pod względem liczby uczniów zamiejscowych w szkołach ponadgimnazjalnych Włocławka wyraźnie dominuje gmina Brześć Kujawski (165 uczniów). W przedziale od 50-100 uczniów mieszczą się gminy: Dobrzyń n./ Wisłą (84 uczniów), Lubień Kujawski (80 uczniów), Fabianki (77 uczniów), Choceń (75 uczniów), Osięciny (75 uczniów), gmina wiejska Włocławek (70 uczniów), Lubanie (61 uczniów). Znaczna część gmin mieści się w przedziale od 10-49 uczniów (15 gmin).

Pod względem udziału kształcących się we Włocławku w ogólnej liczbie osób w wieku 15-19 lat, najwyższa wartość cechuje gminę Brześć Kujawski (20,17\%), Lubanie (18,83\%), gminę miejską Kowal (17,57\%) oraz gminę Bobrowniki $(17,56 \%)$. Udziałem $\geq 10 \%$ charakteryzują się ponadto gminy: Bąd- 
kowo (16,1\%), Baruchowo (15,72\%), Dobrzyń n./Wisłą (15,36\%), Boniewo $(14,62 \%)$, Choceń $(14,04 \%)$, Osięciny $(13,91 \%)$, gminę wiejską Włocławek $(13,79 \%)$, Fabianki $(12,13 \%)$ i Chodecz $(11,44 \%)$. W grupie gmin z udziałem uczniów w grupie wiekowej $15-19$ lat od 5-9\% znalazło się 7 gmin, w tym jedna z województwa Wielkopolskiego (Przedecz).
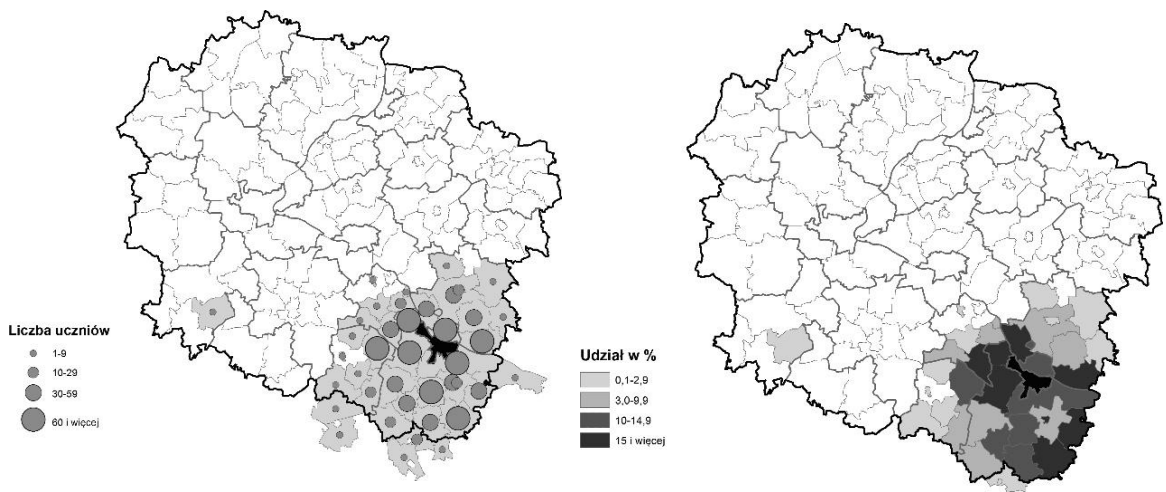

Ryc. 3. Liczba uczniów zamiejscowych i ich udział w ogólnej liczbie młodzieży w wieku 15-19 lat

źródło: opracowanie własne na podstawie badań ankietowych

Weryfikacja gmin pod względem oddziaływań szkolnictwa ponadgimnazjalnego Włocławka wg wyłonionych kryteriów pozwoliła na wyodrębnienie 8 gmin w strefie o silnym oddziaływaniu (Brześć Kujawski, Dobrzyń n./Wisłą, Lubień Kujawski, Fabianki, Choceń, Osięciny, Włocławek-gmina wiejska, Lubanie). 2 z 8 ww. gmin to gminy poza powiatem włocławskim. Wyodrębniono 12 gmin w strefie o słabszym oddziaływaniu, co potwierdza generalnie dość szeroki zasięg oddziaływania szkolnictwa ponadgimnazjalnego we Włocławku (odpowiada to, sygnalizowanej w diagnostycznej części opracowania, najszerszej ofercie szkolnictwa we Włocławku).

Przeprowadzone badanie dla Włocławka potwierdza silniejsze niż np. w przypadku Grudziądza i Inowrocławia ciążenie związane ze szkolnictwem ponadgimnazjalnym. Liczba gmin powiązanych $\mathrm{z}$ Włocławkiem jest w tym przypadku większa niż w Inowrocławiu czy Grudziądzu (zapewne wynika to z szerokiej oferty szkolnictwa we Włocławku i większej liczby szkół w porównaniu z Inowrocławiem i Grudziądzem). 
Tabela 6. Wykaz gmin w strefie silnych i słabych oddziaływań szkolnictwa ponadgimnazjalnego z Włocławkiem

\begin{tabular}{|c|c|c|c|c|c|}
\hline Lp. & Gmina & Powiat & $\begin{array}{l}\text { Liczba uczniów } \\
\text { zamiejscowych }\end{array}$ & $\begin{array}{l}\text { Liczba osób } \\
\text { w wieku } \\
\text { 15-19 lat }\end{array}$ & $\begin{array}{l}\text { Odsetek } \\
\text { uczniów } \\
\text { w wieku } \\
\text { 15-19 lat }\end{array}$ \\
\hline \multicolumn{6}{|c|}{ Strefa silnych oddziaływań } \\
\hline 1 & Brześć Kujawski & włocławski & 165 & 818 & 20,17 \\
\hline 2 & $\begin{array}{l}\text { Dobrzyń nad } \\
\text { Wisłą }\end{array}$ & lipnowski & 84 & 547 & 15,36 \\
\hline 3 & Lubień Kujawski & włocławski & 80 & 527 & 15,18 \\
\hline 4 & Fabianki & włocławski & 77 & 635 & 12,13 \\
\hline 5 & Choceń & włocławski & 75 & 534 & 14,04 \\
\hline 6 & Osięciny & radziejowski & 75 & 539 & 13,91 \\
\hline 7 & $\begin{array}{l}\text { Włocławek- } \\
\text { gmina }\end{array}$ & włocławski & 70 & 464 & 13,79 \\
\hline 8 & Lubanie & włocławski & 61 & 324 & 18,83 \\
\hline \multicolumn{6}{|c|}{ Strefa słabszych oddziaływań } \\
\hline 1 & Bądkowo & aleksandrowski & 47 & 292 & 16,1 \\
\hline 2 & Chodecz & włocławski & 47 & 411 & 11,44 \\
\hline 3 & Lubraniec & włocławski & 47 & 645 & 7,29 \\
\hline 4 & Bobrowniki & lipnowski & 46 & 262 & 17,56 \\
\hline 5 & Kowal-miasto & włocławski & 42 & 239 & 17,57 \\
\hline 6 & Boniewo & włocławski & 37 & 253 & 14,62 \\
\hline 7 & Baruchowo & włocławski & 36 & 229 & 15,72 \\
\hline 8 & Wielgie & lipnowski & 36 & 507 & 7,1 \\
\hline 9 & Topólka & radziejowski & 29 & 339 & 8,55 \\
\hline 10 & Kowal-gmina & włocławski & 22 & 271 & 8,12 \\
\hline 11 & Waganiec & aleksandrowski & 20 & 322 & 6,21 \\
\hline 12 & Przedecz & kolski & 14 & 248 & 5,65 \\
\hline
\end{tabular}

źródło: opracowanie własne na podstawie badań ankietowych 


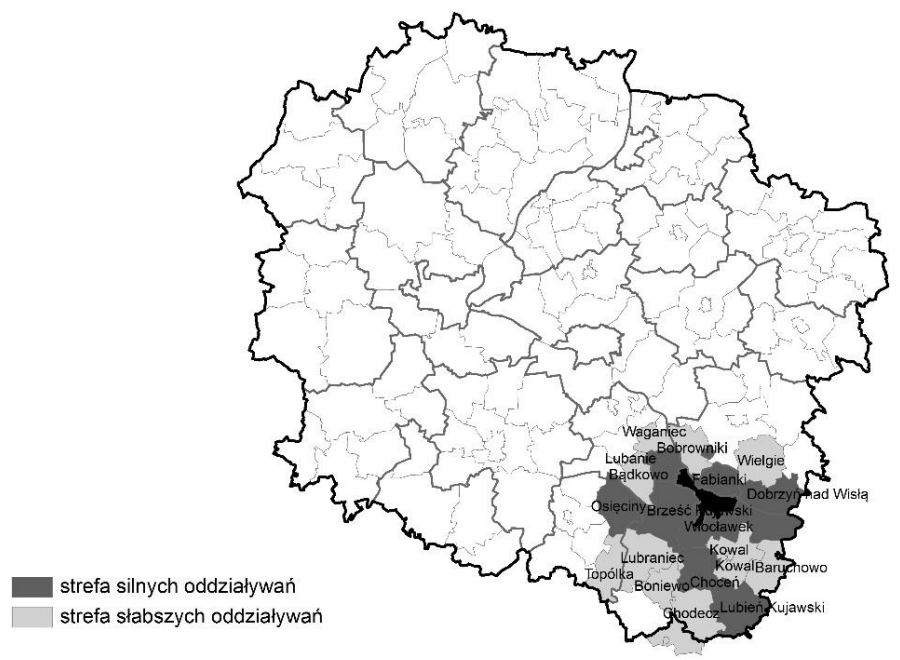

Ryc. 4. Strefy oddziaływań szkolnictwa ponadgimnazjalnego Włocławka Źródło: opracowanie własne na podstawie badań ankietowych

\section{Inowroclaw}

Dane dotyczące liczby i miejsca zamieszkania uczniów szkół ponadgimnazjalnych w Inowrocławiu pozyskane zostały z 8 szkół (2 techników, 3 zasadniczych szkół zawodowych, 2 szkół policealnych i 1 liceum ogólnokształcącego). Z przekazanych przez dyrekcje szkół ankiet zebrano dane dotyczące 1645 uczniów, z których 879 stanowili uczniowie pozamiejscowi (spoza Inowrocławia). Uczniowie pozamiejscowi uczęszczający do szkół ponadgimazjalnych stanowili 53,4\% ogółu uczniów uczęszczających do ww. szkół objętych badaniem.

W odniesieniu do całkowitej liczby uczniów szkół ponadgimnazjalnych kształcących się w Inowrocławiu badaniem objęto 11,8\% uczniów (39\% uczniów techników, 23,7\% uczniów zasadniczych szkół zawodowych, 29,6\% uczniów szkół policealnych i 8,7\% uczniów liceów ogólnokształcących).

Jak wynika z przeprowadzonego badania ankietowego, największa liczba uczniów zamiejscowych kształcących się w szkołach ponadgimnazjalnych zamieszkuje gminę wiejską Janikowo (158 uczniów), która bezpośrednio graniczy z gminą miejską Inowrocław. Wysoką liczbą uczniów dojeżdżających do szkół ponadgimnazjalnych w Inowrocławiu cechuje się również gmina Kruszwica (100 uczniów) oraz gmina wiejska Inowrocław (97 uczniów). Ponadto w prze- 
dziale od 50-100 uczniów znalazły się również gminy: Złotniki Kujawskie (90 uczniów), Pakość (88 uczniów), Gniewkowo (81 uczniów). Liczbą uczniów zamiejscowych dojeżdżających do Inowrocławia do szkół ponadgimnazjalnych od 10-49 uczniów cechuje się m.in. gmina Barcin (49 uczniów), gmina Rojewo (48 uczniów), Dąbrowa Biskupia (46 uczniów), Strzelno (38 uczniów), Jeziora Wielkie (12 uczniów), Piotrków Kujawski (11 uczniów).

Największy odsetek osób w wieku 15-19 lat uczęszczających do szkół ponadgimnazjalnych w Inowrocławiu charakteryzuje głównie gminy powiatu inowrocławskiego. Sa to gminy: Janikowo (17,32\%), Rojewo (15,29\%), Złotniki Kujawskie (14,63\%), Pakość (13,33\%), gmina wiejska Inowrocław (11,81\%). Mniejsze wartości cechują gminę Gniewkowo $(11,81 \%)$ i Kruszwica $(7,86 \%)$, w pozostałych gminach udział ten jest niewielki (poniżej 5\%).
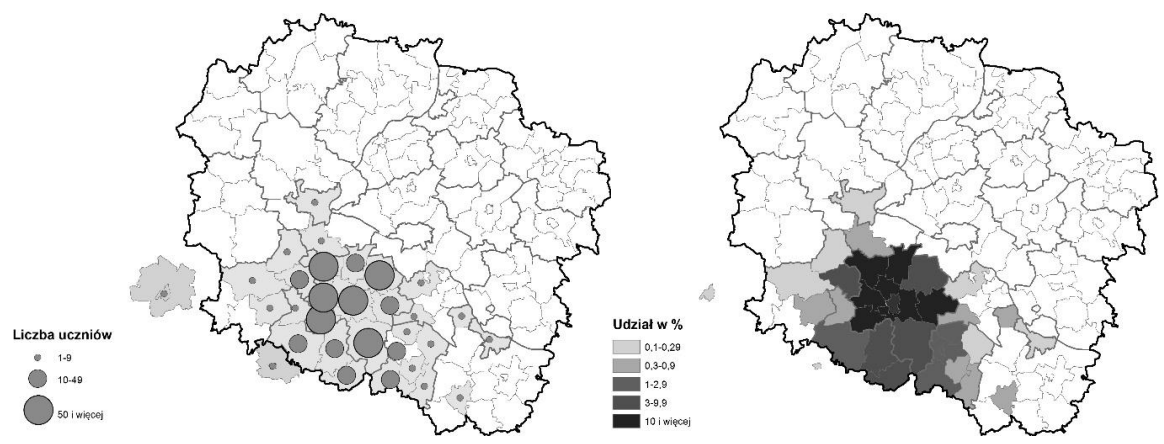

Ryc. 5. Liczba uczniów zamiejscowych i udział w ogólnej liczbie młodzieży 15-19 lat

Źródło: opracowanie własne na podstawie badań ankietowych.

Tabela 7. Wykaz gmin spełniających kryteria przyjęte dla obszarów silnych i słabych oddziaływań szkolnictwa ponadgimnazjalnego z Inowrocławiem

\begin{tabular}{|c|c|c|c|c|c|}
\hline Lp. & Gmina & Powiat & $\begin{array}{c}\text { Liczba uczniów } \\
\text { zamiejscowych }\end{array}$ & $\begin{array}{c}\text { Liczba osób } \\
\text { w wieku } \\
15-19 \text { lat }\end{array}$ & $\begin{array}{c}\text { Odsetek uczniów } \\
\text { w wieku } \\
15-19 \text { lat }\end{array}$ \\
\hline \multicolumn{7}{|c|}{ Strefa silnych oddziaływań } \\
\hline 1 & Janikowo & inowrocławski & 158 & 912 & 17,32 \\
\hline 2 & $\begin{array}{c}\text { Inowrocław- } \\
\text { gmina }\end{array}$ & inowrocławski & 97 & 821 & 11,81 \\
\hline 3 & Złotniki Kujawskie & inowrocławski & 90 & 615 & 14,63 \\
\hline 4 & Pakość & inowrocławski & 88 & 660 & 13,33 \\
\hline
\end{tabular}


Tabela 7. Cd.

\begin{tabular}{|c|c|c|c|c|c|}
\hline \multicolumn{5}{|c|}{ Strefa słabszych oddziaływań } \\
\hline 1 & Kruszwica & inowrocławski & 100 & 1273 & 7,86 \\
\hline 2 & Gniewkowo & inowrocławski & 81 & 938 & 8,64 \\
\hline 3 & Rojewo & inowrocławski & 48 & 314 & 15,29 \\
\hline 4 & Dąbrowa Biskupia & inowrocławski & 46 & 316 & 14,56 \\
\hline
\end{tabular}

Źródło: opracowanie własne na podstawie badań ankietowych.

Miasto Inowrocław wykazało się nieco słabszymi oddziaływaniami szkolnictwa ponadgimnazjalnego w porównaniu z Grudziądzem i Włocławkiem. Do strefy o silnym oddziaływaniu zaliczono 4 gminy powiatu inowrocławskiego: Janikowo, Inowrocław - gminę wiejską, Złotniki Kujawskie, Pakość. Do strefy o słabszych powiązaniach zaliczono 4 gminy: Gniewkowo, Kruszwicę, Rojewo, Dąbrowę Biskupią. Pomimo spełnienia kryterium 1, Kruszwica nie została zaliczona do strefy o silnych oddziaływaniach z Inowrocławiem $\mathrm{z}$ uwagi na niespełnienie kryterium 2 (podobnie w przypadku gmin słabszej strefy oddziaływań: Barcina, Strzelna, Mogilna, Jezior Wielkich, Piotrkowa Kujawskiego). Zarówno strefa silnych, jak i słabszych oddziaływań obejmuje wyłącznie gminy powiatu inowrocławskiego (wszystkie gminy powiatu inowrocławskiego wchodzą w skład jednej ze stref).

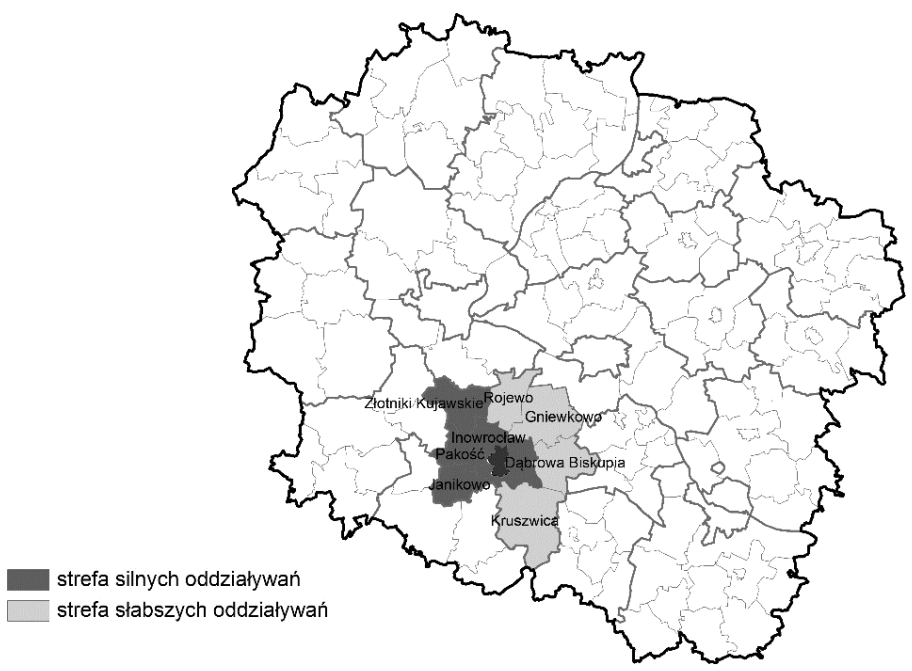

Ryc. 6. Strefy oddziaływań szkolnictwa ponadgimnazjalnego Inowrocławia Źródło: opracowanie własne na podstawie badań ankietowych. 


\section{Podsumowanie}

Ponadlokalne zasięgi oddziaływania szkolnictwa najdogodniej jest badać na przykładzie szkół ponadgimnazjalnych. Rozmieszczenie szkół średnich przeważnie w ośrodkach rangi powiatowej powoduje, że ich zasięg jest często ponadgminny. W przypadku tych szkół istnieje możliwość swobodnego ich wyboru, bez konieczności uzyskiwania jakichkolwiek zgód dyrekcji, tak jak jest to w przypadku szkolnictwa podstawowego i gimnazjalnego, gdy dziecko uczęszcza do szkoły pozaobwodowej.

Badania dojazdów do szkół powinny być bezwzględnie analizowane przez organy prowadzące placówki ponadgimnazjalne. Jak wskazuje Guzik (2003), dostępność przestrzenna szkolnictwa jest jednym z czynników wpływających na poziom wykształcenia społeczeństwa. Dostępność przestrzenna, czasowa i ekonomiczna wpływają na zadowolenie mieszkańców z usług edukacyjnych, a przede wszystkim warunkują możliwość skorzystania z nich.

Wykonane badanie dla Grudziądza, Włocławka i Inowrocławia potwierdza teze, że „rozmiar ciążeń i kierunki dojazdów ściśle zależą od wielkości ośrodka szkolnictwa średniego" Plaza (2012). W przypadku Włocławka strefa silnych oddziaływań szkolnictwa ponadgimnazjalnego jest większa niż w przypadku Inowrocławia, którego ranga pod względem usług edukacyjnych jest niższa w badanym systemie osadniczym.

W delimitacji miejskich obszarów funkcjonalnych Grudziądza, Włocławka i Inowrocławia, obok pochodzenia terytorialnego uczniów szkół ponadgimnazjalnych, zbadane zostały m.in.: kierunki i natężenie dojazdów do pracy, dostępność transportowa, kryterium współpracy samorządowej. Na podstawie uzyskanych wyników badań, stwierdzić można, że strefy dojazdów do szkół ponadgimnazjalnych są znacznie większe niż w przypadku dojazdów do pracy. Wynika to $\mathrm{z}$ redystrybucji placówek szkolnych w przestrzeni oraz powiatowej organizacji szkolnictwa ponadgimnazjalnego, a przede wszystkim z mniejszej liczby szkół ponadgimnazjalnej niż zakładów pracy, zlokalizowanych w badanych miastach.

\section{Spis literatury}

Bajerski A. (2011), Organizacja przestrzenna i funkcjonowanie ustug edukacyjnych $w$ aglomeracji poznańskiej, Bogucki Wydawnictwo Naukowe, Poznań.

Bul R. (2013), Migracje wahadłowe mieszkańców aglomeracji poznańskiej w okresie intensywnej suburbanizacji. Rozprawa doktorska napisana Instytucie Geografii Społecz- 
no-Ekonomicznej pod kierunkiem Prof. dr hab. Tomasza Kaczmarka, Uniwersytet im. Adama Mickiewicza w Poznaniu.

Guzik R. (2003), Interpretacja przestrzennej dostęności szkót ponadpodstawowych w oparciu o metode ilorazu potencjałów, w: H. Rogacki (red.), Problemy interpretacji wyników metod badawczych stosowanych w geografi spoleczno-ekonomicznej i gospodarce przestrzennej, Bogucki Wydawnictwo Naukowe, Poznań.

Maik W. (1992), Podstawy geografii miast, Wydawnictwo Uniwersytetu Mikołaja Kopernika, Toruń.

Plaza M. (2012), Powiazania w zakresie dojazdów do szkót, w: R. Guzik (red.), Czynniki i ograniczenia rozwoju miast województwa pomorskiego $w$ świetle relacji przestrzennych i dostępności komunikacyjnej, UMWP, Gdańsk.

Walaszek M. (2012), Szkolnictwo ponadgimnazjalne, w: T. Kaczmarek (red.), Studium uwarunkowań rozwoju przestrzennego aglomeracji poznańskiej, CBM UAM, Poznań.

\section{Wykaz dokumentów}

Czapiewski K. Ł., Kozak M., Śleszyński P. (2011), Znaczenie ośrodków miejskich oraz ich hierarchicznych powiazań dla regionalnego i lokalnego rozwoju ekonomicznego i spotecznego Polski Wschodniej, ekspertyza wykonana na zalecenie MRR, Warszawa.

Koncepcja Przestrzennego Zagospodarowania Kraju 2030 (KPZK 2030), 2012 r. - Monitor Polski (poz. 252).

Określenie specyfiki oraz przygotowanie propozycji delimitacji miejskich obszarów funkcjonalnych Włocławka, Grudziądza i Inowrocławia, opracowanie dla Urzędu Marszałkowskiego Województwa Kujawsko-Pomorskiego, CBM UAM Poznań, 2013.

Strategia rozwoju województwa kujawsko-pomorskiego do roku 2020.

Ustawa o systemie oświaty z dnia 7 września 1991.

\section{The teritorial origin of secondary school students as a delimitation criterium of urban functional areas of Włocławek, Grudziądz and Inowrocław}

\section{Summary}

The aim of the publication is the presentation of the research method of teritorial origin of secondary school students on the examples of Włocławek, Grudziądz and Inowrocław and 
its implications in defining the range of influence of secondary schools. The results of the research were used to define the spatial, functional connections with the surrounding of two regional centres of kujawsko-pomorskie voivodeship - Grudziądz and Włocławek as well as a subregional centre - Inowrocław.

Keywords: secondary schools, teritorial origin of secondary school students, urban functional area. 